PART 4

Neoliberal Governmentality 
Mark Olssen - 9789004464452

Downloaded from Brill.com04/26/2023 05:21:01AM via free access 


\title{
Neoliberalism and Laissez-Faire
}

\author{
The Retreat from Naturalism
}

\begin{abstract}
This article starts by restating the core theoretical differences between liberalism and neoliberalism, most essentially concerning the principle of the active or positive state that I have claimed characterizes neoliberal governmentality, premised upon a distinction between naturalistic and anti-naturalistic views of state functioning and entailing the abandonment or severe qualification of laissez-faire. Of the differences between liberal and neoliberal government, I will recommit to my original thesis of the distinction between the positive state and the erosion of laissez-faire, as well as to the distinction between naturalism and anti-naturalism as being important to understanding the two variants of liberalism and to understanding as well the anti-democratic tendencies of the neoliberal variant. Here I will maintain that the key neoliberals in a theoretical sense are the European ordoliberals, such as Walter Eucken and Wilhelm Röpke, as well as US writers such as James Buchanan (public choice theory) and Henry Simons, while others such as Friedrich Hayek, although politically mobilizing for and actively supporting the advent and ascendency of neoliberalism, as witnessed by his formative role in establishing the Mont Pelerin Society, were, I will argue, much more cautious about jettisoning laissez-faire and of adopting an anti-naturalistic perspective. After setting out the distinctive features that characterize neoliberalism, the consequences for education will be briefly investigated.
\end{abstract}

\section{The Problem of Laissez-Faire in Neoliberal Thought ${ }^{1}$}

Foucault's (2008) analysis of the ordoliberals in Germany focused on the discrepancy between their advocacy of laissez-faire and the polarity between their views on the role of government. On the one hand, the German ordoliberals distrusted large concentrations of power and opposed action to "interfere" in markets, through wages and price fixing, or administrative or bureaucratic involvement, but on the other hand, they favoured and supported the actions of government to reinforce and strengthen the institutional infrastructures, to arrange and enable the "conditions" necessary for the market to operate. This was supported, for instance, by ordoliberals such as Walter Eucken, who took the view that the economy required an "economic constitution", which must

(C) SLOVENSKO DRUŠTVO RAZISKOVALCEV ŠOLSKEGA POLJA IN PEDAGOŠKI INŠTITUT, 2018 DOI: $10.1163 / 9789004464452 \_010$ 
be created and protected by the state. The possible conflict with free market principles is evident in the following statement:

A solution of this task of which much depends (not only men's economic existence), requires the elaboration of a practicable economic constitution which satisfies certain basic principles. The problem will not solve itself simply by our letting economic systems grow up spontaneously. The history of the last century has shown this plainly enough. The economic system has to be consciously shaped. (Eucken, 1940/1992, p. 314)

Eucken sought to chart the basic principles of "economic politics" (Wirtschaftspolitik) in order to establish the "conditions" for a competitive market order to arise and continue. Establishing competition as the cornerstone of the economy became the key principle of a neoliberal order. It was concerned not with "interfering" with the day-to-day processes of the economy, but seeking to establish and protect the "conditions" that were favourable to an effective and efficient economic system. As Eucken put it, "[t]he answer is that the state should influence the forms of economy, but not itself direct the economic process" (1940/1992, p. 95).

It was also supported amongst the US free market advocates, such as Henry Calvert Simons. As "father" of the Chicago School of free market economics, Simons was expected to champion a consistently traditional approach accepting the classical postulates of laissez-faire. This was as a natural equilibrium between supply and demand which ensured the "self-regulation" of the economy, as if directed, in Adam Smith's phrase, by an "invisible hand", i.e., laws of nature. Yet, in his pamphlet, $A$ Positive Program for Laissez-faire, first published in 1934, Simons seems ambivalent over laissez-faire:

The representation of laissez-faire as a merely do nothing policy is unfortunate and misleading. It is an obvious responsibility of the state under this policy to maintain the kind of legal and institutional framework within which competition can function effectively as an agency of control. The policy should therefore be defined positively, as one under which the state seeks to establish and maintain such conditions that it may avoid the necessity of regulating "the heart of the contract" - that is to say, the necessity of regulating relative prices. Thus, the state is charged, under this "division of labor", with heavy responsibilities and large "control" functions: the maintenance of competitive conditions in industry, the control of the currency, ... the definition of the institution of property, ... not to mention the many social welfare functions. (Simons, 1948, p. 42) 
Indeed, Ronald Coase was so shocked at Simons's pamphlet that he questioned Simons's credentials as a classical liberal and free market advocate:

I would like to raise a question about Henry Simons. ... [His] Positive Program for Laissez-faire ... strikes me as highly interventionist pamphlet. ... [I]n antitust, [Simons] wanted to ... restructure American industry. ... In regulation ... he proposed to reform things by nationalization. ... I would be interested if someone could explain. (Cited in Kitch, 1983, pp. 178-179)

Coase maintains that Simons's Positive Program constitutes a blueprint for intrusive state interventions in the market of the sort advocated by social democrats and socialists who Simons most vehemently opposed and who advocated forms of state regulation of economic processes because they distrusted unregulated marketplace interactions. According to J. Bradford De Long of Harvard University, who also cites the quotation above (1990, p. 601), Coase's question (above) raised some interesting responses:

Simons' former Chicago pupils, his successors as upholders of classical liberalism in economics, did not rise to his defense. Instead, they responded as follows: First, they acknowledged that Simons was not a pure liberal, but at best a mixed breed. "You can paint him with different colors ... ", said Harold Demsetz. "It's quite a mixed picture", said George Stigler. Second, they admitted that Simons was an "interventionist", that he did not believe that, in general, economic activity should be organized through free markets. " $[\mathrm{H}] \mathrm{e}$ was the man who said that the Federal Trade Commission should be the most important agency in government, a phrase that surely should be on no one's tombstone", joked Stigler; "Everything Ronald [Coase] says is right". And Milton Friedman joined in: "I've gone back and reread the Positive Program and been astounded. ... To think that I thought at the time that it was strongly pro-free market in orientation!" (Cited in De Long, 199o, pp. 6o1-6o2)

Not only did Simons advocate regulation, but he even advocated nationalization. As Simons states in his pamphlet:

Political control of utility charges is imperative ... for competition simply cannot function effectively as an agency of control. ... In general ... the state should face the necessity of actually taking over, owning, and managing directly, both railroads and utilities, and all other industries to which it is impossible to maintain effectively competitive conditions. (Simons, 1948, p. 57) 
De Long defends Simons as a classical liberal on the grounds that "[Simons] thought that a primary function of government in a free society is to manage competition" (De Long, 199o, p. 610). Simons represented a strain of thinking in liberal economics that had been prominent in Europe in the work of the German ordoliberals, foremost amongst them economists such as Eucken and Röpke, who distinguished the "conditions" necessary to sustain a free market economy from the intervention of the government in the processes or actual functioning of the economy itself.

State intervention is necessary for the ordoliberals in order to establish the conditions under which laissez-faire can effectively operate. Indeed, Eucken appears to be quite dismissive of what is central to laissez-faire:

The solution to the problem of control was seen by [the advocates of laissez-faire] to be in the "natural" order, in which competitive prices automatically control the whole process. They thought that this natural order would materialise spontaneously and that society did not need to be fed a "specific diet", that is, have an economic system imposed on it, in order to thrive. Hence, they arrived at a policy of laissez-faire; this form of economic control left much to be desired. Confidence in the spontaneous emergence of the natural order was too great. (Eucken, 1989, p. 38)

This interventionist current in liberal thought was alive and well in America amongst other liberals than Henry Simons. James Buchanan, the founder of public choice theory, shares with the ordoliberals this more directive orientation to state action. Although the classical liberal tradition had stressed the role of markets as "self-regulating", representing a strong commitment to liberalism as a naturalistic doctrine, and as supported by arguments based on the freedom of the individual from the state, Buchanan so distrusted that the required efficiency gains would emerge through automatic mechanisms of the market that, in a way similar to writers like Röpke and Eucken, he supported efficiency achievements through a the deliberate tightening of state control. As he says in his criticism of Hayek:

My basic criticism of F. A. Hayek's profound interpretation of modern history and his diagnosis for improvement is directed at his apparent belief or faith that social evolution will, in fact, ensure the survival of efficient institutional forms. Hayek is so distrustful of man's explicit attempts of reforming institutions that he accepts uncritically the evolutionary alternative. (1975, p. 194n) 
It was on this ground that he opposed Hayek's naturalist faith in markets as spontaneous self-ordering systems which had been the hallmark of the classical liberal view since its inception. In Buchanan's view, the state should actively construct the competitive market economy and utilise supply-side monitoring in the interests of promoting efficiency in market terms.

\section{$2 \quad$ Foucault, Röpke and Neoliberalism}

Michel Foucault studied neoliberalism in his 1978 course at the Collège de France, The Birth of Biopolitics. For Foucault, neoliberalism signals "a shift from exchange to competition in the principle of the market" (2008, p. 118). Competition assumes the role of a fundamental principle that subtends democracy, which is to say, that the basic ordering of society as an enterprise culture structured by competition is to be enforced by government across all domains of the society. It becomes, as it were, the organising framework guaranteed by the state rather than as a function of the market. Foucault marshals evidence by citing Eucken who tells us that the government must be "perpetually vigilant and active" (p. 138), and must intervene to establish this context through both regulatory actions (actions régulatrices) and organizing actions (actions ordonnatrices) (p. 138).

Although during the first half of the 2oth century Western welfare states were constituted through democratic determination, the accomplishment of neoliberalism, for the ordoliberals at least, was to attempt to establish the principle of competition as prior to and outside of democratic decision-making; as determining the "framework" through which the market would rule. The framework must attend to both the population, the order of justice and opportunity, as well as the techniques, such as the availability of implements concerning such things as population, technology, training and education, the legal system, the availability of land, the climate, all seen by Eucken as the "conditions" for the market. Foucault refers to this active, top-down, positive role of the state as constituting a "sociological liberalism" (p. 146, footnote 51), or a "policy of society" (p. 146) which permits a new "art of government" which differs radically from Keynesian-type systems. What is crucial is that for neoliberalism the object of government action becomes "the social environment" (p. 146) acting on behalf of capital, or those the create wealth. The aim is to engineer competition:

It is the mechanisms [of competition] that should have the greatest possible surface and depth and should also occupy the greatest possible 
volume in society. This means that what is sought is not a society subject to the commodity effect, but a society subject to the dynamic of competition. (p. 147)

Competition becomes the new "eidos" (p. 147), the new dynamic of this new form of society:

Not a supermarket society, but an enterprise society. The homo oeconomicus sought after is not the man of exchange, or man the consumer; he is the man of enterprise and production. (p. 147)

Wilhelm Röpke fundamentally sets out the neoliberal social policy in his text "The Orientation of German Economic Policy", where he says that social policy must aim at:

the multiplication of the enterprise form within the social body. ... It is a matter of making the market, competition, and so the enterprise, into what could be called the formative power of society. (Cited by Foucault, p. 148)

In his book A Humane Economy: The Social Framework of the Free Market (1958/1971), Röpke's new form of liberalism becomes even more readily apparent. The book aims to establish the appropriate foundations of the market economy by outlining the conditions necessary for the free market beyond the previously accepted context of supply and demand. For such a market order cannot function, he says, "in a social system which is the exact opposite in all respects" (p. 94). The cultural context of the social structure is part of this and must support this:

We start from competition. ... Competition may have two meanings: it may be an institution for stimulating effort, or it may be a device for regulating and ordering the economic process. In the market economy competition ... constitutes therefore an unrivalled solution of the two cardinal problems of any economic system: the problem of the continual inducement to maximum performance and the problem of continuous harmonious ordering and guidance of the economic process. (p. 95)

The foundation for this is not laissez-faire; Röpke, like Eucken, and like Simons, is not describing a naturalistic but has succumbed to advocating a historical thesis. Laissez-faire was the naïve thesis of early liberalism. For Röpke it was a fiction: 
In all honesty, we have to admit that the market economy has a bourgeois foundation. ... The market economy, and with it social and political freedom, can thrive only as a part and under the protection of a bourgeois system. This implies the existence of a society in which certain fundamentals are respected and color the whole network of social relationships. (p. 98)

Röpke's conception of liberalism is clearly more authoritarian in the sense that it seems to represent an imposed order. Such a view seems reinforced when he acknowledges that:

In a sound society, leadership, responsibility, and exemplary defense of society's guiding norms and values must be the exalted duty and unchallengeable right of a minority that forms and is willingly and respectfully recognized as the apex of the social pyramid hierarchically structured by performance. ... What we need is true nobilitas naturalis. ... We need a natural nobility whose authority is, fortunately, readily accepted by all men, an elite deriving its title solely from supreme performance and peerless moral example and invested with the moral dignity of such a life. ... No free society ... which threatens to degenerate into mass society, can subsist without such a class of censors. (p. 131)

Röpke adds that "the task of leadership falls to the natural aristocracy by virtue of an unwritten but therefore no less valid right which is indistinguishable from duty" (p. 133). Only such persons can save us from the "slowly spreading cancers of our western economy and society" (p. 151), which include the "irresistible advance of the welfare state" (p. 151).

\section{3}

\section{Hayek and Neoliberalism}

Did Friedrich Hayek also accept this new view of "economic politics"? My answer is not in the same sort of way, although he shared the pro-free market values that they supported. Hayek was too steeped in the classical liberal tradition to easily give up its naturalistic assumptions concerning laissez-faire and the conception of the subject who should be trusted as a rational, autonomous citizen and who should remain unconditioned or uncoerced by the state. Yet the theoretical difficulties that afflicted Simons, Buchanan, Eucken, and Röpke, also weighed heavily on Hayek. He not only struggled with the notion of laissez-faire, but also appreciated that over time the democratic will of citizens 
tends to favour restrictions on the free market economics and supports an expanded role for government as respects to both welfare and redistribution. ${ }^{2}$

Although I have written several articles and chapters on Hayek, one is always learning new things. In a PhD doctoral viva voce examination on Foucault and neoliberalism that I had the honour to examine at the University of Brighton in 2018, Lars Cornelissen, the disputant, alerted me to several works of Hayek that I had been unaware of. One was an article by Hayek, titled "Marktwirtschaft und Wirtschaftspolitik", 3 published in the journal ORDO in 1954 where Hayek laments the fact that classical economists had not adequately defined "intervention" because, as Cornelissen summarizes Hayek's view, "many of them held 'economic politics', of the sort advocated by Eucken and Röpke, to be antithetical to 'the fundamental principles of liberalism'" (Cornelissen, 2017, p. 206; citing Hayek, 1954, p. 4).

Being aware of the controversy between classical liberalism and the "economic politics" of Eucken and Röpke, Hayek is more careful to limit the active role of the state to establishing the juridical structure of society. For Hayek, the creation and maintenance of a competitive order is primarily a legal affair. The only type of intervention for an "economic politics" is in the "permanent juridical framework" as opposed to "constant intervention of state force [Staatsgewalt]" (Cornelissen, p. 206; Hayek, p. 5). Hayek thus restricts intervention of the state to the legal order and thus has a much narrower view of active state intervention to establish the "conditions" of economic activity than does either Röpke or Eucken.

Throughout his career Hayek remained steadfastly committed to the idea that markets best guaranteed the freedom of citizens, and on this ground remained staunchly opposed to all forms of state planning and control. What essentially undermines state planning in Hayek's view is that real knowledge is gained and true economic progress made as a consequence of locally generated knowledge derived from "particular circumstances of time and place" and the state is not privy to such knowledge (Hayek, 1949b, p. 79). Planning ignores this localistic character of knowledge and thus interferes with the self-regulating mechanism of the market.

It is on these grounds that Hayek argues that the state should only be concerned with the protection of individuals by "general rules", such as the "rule of law", but not with what he refers to as "central planning". If we look to Hayek, both to The Road to Serfdom (1944) and The Constitution of Liberty (1960), where 
Hayek discusses planning and the rule of law, in contrast to the rule of law's formal, and a priori character, the plan's approach to decision-making is ad hoc and arbitrary. A plan also embodies, says Hayek (1944, p. 91) "substantive" commitments on ends and values, whereas the rules constitutive of the rule of law are "general", "formal", "impartial" and "systematic" (pp. 9o-92). Formal rules operate "without reference to time and place or particular people" (p. 92). They refer to "typical situations. ... Formal rules are thus merely instrumental in the sense they are expected to be useful to yet unknown people" (p. 92). On the other hand, planning involves "a conscious direction towards a single aim" (1944, p. 72), and "refuses to recognize various autonomous spheres in which the ends of individuals are supreme" (p. 72) As such the plan embodies general substantive goals linked to the "the general welfare', or the 'common good', or the 'general interest'" (p. 72). Yet, it is Hayek's view that the welfare of people "cannot be adequately expressed as a single end" (p. 73) for to have such a conception of the general welfare requires a "complete ethical code", which would require knowledge of everything. The difference between the two kinds of approach, says Hayek, is like the difference between the "Rules of the Road', as in the Highway Code, and ordering people where to go" (1944, p. 91).

\section{5}

A Critique of Hayek's Concept of Planning

Hayek acknowledges that while his distinction between formal rules, and planning "is very important ... at the same time [it is] most difficult to draw precisely in practice" (1944, p. 91). This, it seems to me, understates what is problematic about his argument. While his points about the need for general rules that are formal, and apply to all, are highly important, his characterization of planning is largely a caricature, and his arguments against it do not stand serious scrutiny. Indeed, it would seem, as many economists in his own Department at the LSE believed, that any serious analysis of Hayek's arguments leads us straight to Keynesian conclusions. ${ }^{4}$

Hayek's arguments against central planning have been seriously challenged. ${ }^{5}$ What is conflated in his treatment is a failure to distinguish "central planning", as exemplified by the model of the Soviet Union, and aspects of planning in general, as adopted routinely in Western democracies. ${ }^{6}$ While his arguments may be persuasive against the idea of highly centralized decision-making for the entire economy, beyond this the assessment of his legitimate empirical arguments are difficult to untangle from what is the deeply ingrained ideological nature of his opposition to social democracy or socialism. Certainly the emergence of highly centralized economies of Eastern Europe from the $1920 \mathrm{~s}$ 
could be seen to inhibit the emergence of Schumpeter-styled entrepreneurs, and to erode possibilities for enterprise and initiative. As developed in the Soviet Union after the Revolution of 1917 , the model of state capitalism (capitalisme de parti) which was based on the attempts by a single political party to manage the operations of the economy through the direct transmission of orders from the centre, including the establishment of centralized socialist trusts, involving the direct control of recruitment, production schedules and wages met with severe problems of the sort Hayek describes. Beyond this, however, it can be claimed that the problem is not so much with planning, but with the broader political model in operation.

That Hayek extends his objections from a concern with Soviet-styled central planning to forms of state planning in Western societies, and specifically against those forms of general planning being developed in countries like Britain at the onset of the welfare state, constitutes a major problem. For what can be claimed is that there is no objection to planning as such, nor even to central planning, but only against types of planning that are ad hoc and arbitrary, and not subject to democratic controls of auditing, accountability, contestation, debate and revision. Planning, in fact, is amenable to the same types of assessment as Hayek maintains for the rule of law, and like the rule of law, it should comprise codified procedures which are formal, systematic, a priori (written in advance) and general or impartial. Planning also must be democratically accountable. Planning, in this sense is compatible with open economies, individual initiative, local autonomy in decision-making, and decentralization. ${ }^{7}$

One important issue that Hayek never considers is whether markets and planning could (or should) coexist. That is, whether there is not some middle ground position between the "serfdom" associated with state planning, and the "freedom" associated with markets. As Jim Tomlinson (1990, p. 49, note 3) notes:

[I]n his 1945 article ["The Use of Knowledge in Society"], Hayek typically dismisses any mid-way point between centralised and decentralised planning except "the delegation of planning to organised industries, or, in other words, monopoly" (p. 521). Plainly this does not exhaust the possibilities of levels of planning, nor does it provide a helpful starting point for discussing mechanisms of planning. ${ }^{8}$

\section{$6 \quad$ Knowledge and Planning}

Markets are also preferred to planning on grounds of efficiency and because of the local nature of knowledge. When planning takes the place of markets, 
mistakes and errors become "entrenched" because only the price mechanism can coordinate the diverse activities of individuals, says Hayek. Partly, this is due to the absence of local or contextual knowledge which actors in the marketplace have and state bureaucrats don't have. But, although Hayek distinguishes important characteristics of local knowledge, he fails to consider whether other sorts of knowledge might not be important; or perhaps whether or not knowledge might not work differently at the macro, meso, and micro orders of society. To use Hayek's language, from "The Use of Knowledge in Society", while he celebrates knowledge of "time and place" which is not accessible to planners, he gives no value to the benefits of "aggregated" or "statisticaltype" knowledge, which enables perspective, and which could be held to constitute an equally important type of knowledge which "planners" do have, and which is denied to agents in local contexts. This latter type of knowledge might be claimed to be concerned with general guidelines, limits, or contexts, and coordination, rather than specifically with day-to-day operations. It therefore maintains a different relation to time and place, and hence, the practical problem which Hayek notes about transmitting information about events which are situationally local need not arise. ${ }^{9}$ Certainly, if planning sought to replace or override market mechanisms, or disregard, interfere with, or override local knowledge, one could see that would constitute a serious problem, but this does not mean that markets and planning cannot compliment and assist each other in turn. ${ }^{10}$

Various distinctions could be made which Hayek also does not make, between "normal" versus "exceptional" operations of markets, between the "macro", "meso", or "micro" levels of the economy, or the distinction made above, concerning the context effectively regulated by supply and demand and the price mechanism (where a rough equilibrium may persist for a certain time) versus the context of coordination (requiring macro-management, planning, agenda setting, and steering). While it may well be so that local knowledge and the fragility of the price mechanism means that normal day-to-day operations of markets should be relatively autonomous from the arbitrary interference of the state, there will be exceptional circumstances where "communicating knowledge to a board" for urgent or non-urgent action is highly appropriate. Within normal markets, behaviour which signals exceptional development ("a run on the pound"); or behaviour which signals unusual development ("a contaminated product"; "a suspicious behavior") are cases in point. Just as the doctor-patient relation for the most part is a private contract, evidence of certain types of symptoms must be immediately reported. In addition, there will be routine situations where guiding the economy within established limits require specific actions in line with established policies. Introducing policies 
to counter economic inequalities in capital accumulation, or to assist in creating fair opportunities, also constitute legitimate activities that can be planned for. Hence, there are different sorts of functions which require different types of coordination, and different types of knowledge.

"In a democratic society", wrote Karl Mannheim, "state sovereignty can be boundlessly strengthened by plenary [planning] powers without renouncing democratic control" (1940, p. 340). Yet, Hayek maintains that democratic assemblies have problems producing a plan. Either they cannot manage the whole view, or obtain adequate knowledge, or, if delegated, they cannot integrate it (Hayek, 1944, pp. 82-84). Such a claim is highly dubious, especially given the sophisticated planning instruments and communication technologies available today. But regardless of that, government has responsibility to oversee and steer the whole. The delegation of particular powers to separate boards and authorities is a part of that responsibility. Yet the parliamentary system renders the state as democratically accountable and is as necessary to the formal legitimacy of the rule of law as it is to the formal legitimacy of planning.

Amongst existing democratic mechanisms, parliament is one mechanism of accountability; the official opposition are charged with discussion and debate, and with highlighting abuses, identifying shortcomings, as well as criticizing delegated or contracted groups whose performance is not up to the mark. In addition, the free mass media, as well as institutions of judicial review, make existing democratic assemblies and procedures crucial underwriters to both the formality and generality of policy, whether through law, or planning, and they legitimate both law and planning. It is the democratic assemblies which both enable and legitimate the formality of the rule of law and are accountable for good as opposed to bad legislation. ${ }^{11}$ What Hayek doesn't seem to realize is that they are similarly able to perform this function in relation to planning. Through various codified and formal rules of procedure and process, planning can be legitimate or illegitimate. Hence, I would reject Hayek's thesis that "planning leads to dictatorship" (p. 88) or that "dictatorship is essential if planning on a large scale is to be possible" (p. 88), just as I would reject the thesis that planning is necessarily arbitrary.

Another factor makes planning important here. At the start of the 21st century, collective action and sophisticated planning operations have become increasingly necessary on all manner of issues ranging from matters relating to general security and the response to crisis and urgency, to arranging social insurance, and the provision of opportunities, structures, and capabilities on a fair and equitable basis. Increased pressures associated with global population growth, climate change, ecological degradation, nuclear proliferation, 
terrorism, viral pandemics, or economic or political collapse create a situation in which not planning is simply not an option. Believing that laissez-faire will deliver security and stability for all on a global basis simply constitutes the naïve faith of classical economic liberalism.

While Hayek's opposition to all forms of state planning might be seen as viable if he can argue that the economic system is naturally self-regulating, should this later thesis founder, so the former will also be in difficult straights. Yet, just as we found for Simons, Buchanan, Eucken and Röpke, Hayek's views on the self-regulating capacity of the system, implying laissez-faire, do not inspire confidence. Although he had substituted his "empirical conception" (of laissez-faire) for what he considered to be the inadequate neoclassical conception, his "knowledge papers" of the 193os and 1940s revealed increasing doubts about both its theoretical and practical viability. In his paper "Economics and Knowledge", first presented in 1937, he notes that although traditional experience has more or less confirmed equilibrium theory "since the empirical observation that prices do tend to correspond to costs was the beginning of our science" (1949a, p. 51), his own confidence in the idea was waning. The following statement is not exactly brimming with confidence:

I am afraid that I am now getting to a stage where it becomes exceedingly difficult to say what exactly are the assumptions on the basis of which we assert that there will be a tendency toward equilibrium and to claim that our analysis has an application to the real world. I cannot pretend that I have as yet got much further on this point. Consequently all I can do is to ask a number of questions to which we will have to find an answer if we want to be clear about the significance of our argument. (1949a, p. 48)

In the same article, Hayek observes that both Smith and Ricardo had noted that the stability of community structures were essential preconditions for any equilibrium to operate (1949a, p. 48, note 13). ${ }^{12}$ By 1945, in "The Use of Knowledge in Society", he recognizes that the concept of equilibrium was irrelevant for practical purposes, had "mislead ... leading thinkers" in economics, and he represents it as "no more than a useful preliminary to the study of the main problem" (1949b, p. 91). In "The Meaning of Competition" of 1946, also, he notes how "the modern theory of competitive equilibrium assumes the situation to exist" (1949c, p. 94). In his doubts, expressed across all of these papers, Hayek's was also to observe that even if it can be recast as an empirical proposition, subject to verification, equilibrium theory then becomes only a possibility rather than an actuality. More to the point, Hayek was by no means certain what sorts of empirical tests could validate it, and he very much doubted "whether [any] 
such investigations would tell us anything new" (1949a, p. 55). He also notes how simply to assume equilibrium overlooks the negative externalities and global disparities associated with markets, including increasing inequalities of wealth and resources, and increasingly monopolistic behaviour of large companies and multinationals. His confidence did not improve in later years.

It was related to these doubts that many economists from Hayek's own department-Hicks, Kaldor, Lerner, Scitovsky and Shackle-retreated to Keynesianism under the influence of the Cambridge model in the 193os. Shackle reasoned that given Hayek's conception of history, emphasizing as it did the limits to reason, uncertainty, spontaneous unpredictable choices, as well as the unpredictability of unintended effects at any single point in time we can have little faith in the logical coherence of market equilibrium over time to "self-regulate" unless we believe in a metaphysic of nature as functionally optimal at the economic and social levels, or as tending towards the functionally optimal. If the market cannot be relied upon, then what mechanism can guarantee socially optimal consequences for distribution and for the continuance of the market mechanism as a predictable framework in terms of which economic interactions between humans can be guided? Further, what mechanism can guarantee that the effects of the market are not dysfunctional in relation to the social and physical environment? In Shackle's view, these ideas suggest a coordinative mechanism is required, not to substitute for the rational decisions for individuals, but to ensure distribution, security and liberty and to undertake collective action in areas where individuals are unable to address. For Shackle, and his fellow Keynesians at least, planning was clearly back on the agenda.

Keynes had argued something similar to this in his theoretical justifications for the welfare state. In Keynes's view, as a general consequence of our ignorance of the future, planning was an essential feature of the welfare state. In a letter he wrote to Hayek while on an ocean liner en route to the Bretton Woods Conference in June 1944, after reading Hayek's book The Road to Serfdom, in what could possibly be seen as a case of classic understatement, Keynes (1980, pp. $385^{-388)}$ raises the issue that he regards Hayek as not addressing or resolving:

I come finally to what is really my only serious criticism of the book. You admit here and there that it is a question of knowing where to draw the line. You agree that the line has to be drawn somewhere [between free markets and planning], but that the logical extreme is not possible. But you give us no guidance whatever as to where to draw it. In a sense this is shirking the practical issue. It is true that you and I would probably draw it in different places. I should guess that according to my ideas you greatly under-estimate the practicality of the middle course. But as soon as you 
admit that the extreme is not possible, and that a line has to be drawn, you are, on your own argument, done for since you are trying to persuade us that as soon as one moves an inch in the planned direction you are necessarily launched on the slippery path which will lead you in due course over the precipice. I should therefore conclude your theme rather differently. I should say that what we want is not no planning, or even less planning, indeed I should say that we almost certainly want more.

\section{$7 \quad$ Lars Cornelissen on Hayek and Democracy}

One question that remains for Hayek is how, if the state can intervene only in the legal structures of society through formal processes, is Hayek able to protect free market economics from the possibility of democratic rejection. This is, after all, why Eucken and Röpke wanted state intervention to establish the "conditions" of an enterprise culture in a much broader sense; not only legal, but political, cultural, and educational as well. This is an important question for Hayek especially given his own doubts about the efficacy of laissez-faire. The answer is, as Cornelissen argues, Hayek has a vastly attenuated conception of democracy which:

must give way to a form of constitutionalism that explicitly seeks to eliminate popular sovereignty. This ... does not entail a principled rejection of democracy. Rather, it comprises a far reaching restriction of the democratic mechanism, such that democratic citizens may exert an influence on the governmental apparatus but are simultaneously prevented from changing the overarching legal framework. (2017, p. 222)

Hence, Cornelissen argues that "the primary aim of Hayek's democratic theory is to banish popular sovereignty from political thought" (p. 223).

Noting that Hayek's democratic theory constitutes the "privileged object of analysis for a critical account of the place occupied by democracy in neoliberal thought" (p. 226), Cornelissen starts by noting Hayek's "ambivalence towards democracy" (p. 244), and his decision to limit it to "describe a method of government-namely majority rule" (p. 244). Democracy then constitutes a "method of deciding but emphatically not 'an authority for what the decision ought to be'" (p. 244). In general terms, Hayek claims to support democracy as the best method of change; as the best mechanism compatible with liberty, and as the best method for educating the majority, because it has better results overall. At the same time, Hayek makes frequent negative comments about 
democracy, or aspects of democracy. Cornelissen notes Hayek's antipathy to what he refers to as "the doctrinaire democrat" (cited from Cornelissen, p. 245). In a previous article of my own (Olssen, 2010, chapter 2), I also noted Hayek's disparaging reference to forms of "plebiscitarian dictatorship" (1944, p. 86), which may suggest a rather disrespectful slur on citizens in general. Various negative comments can be found, such as in The Constitution of Liberty (1960), where Hayek says: "[t]hose who profess that democracy is all-competent and support all that the majority wants at any given moment are working for its fall" (196o, p. 183). Cornelissen concedes, however, that as he aged, Hayek "became inclined to mount a principled defense of democratic government" (p. 245). Where he falters, in Cornelissen's view, is in the model democratic constitution he develops in the third volume of Law, Legislation and Liberty. Here, Hayek favours the establishment of both a representative government as well as an upper house legislature, the latter which would "completely be insulated from popular control” (p. 253). As Cornelissen continues:

In Hayek's model constitution, then, the average citizen can exert some influence on the direction of government, thus modestly guiding the allocation of public resources, but has virtually no control over the law, which is articulated by a council, consisting of "wise and fair" legislators, that can neither be recalled nor corrected by the people. In Hayekian democracy, concisely put, each individual citizen is equal before the law over which they can exert no significant control. (pp. 253-254)

It is perhaps unfair to suggest that Hayek's model constitution invokes "echoes" of Plato's Guardians..$^{13}$ Yet, Cornelissen notes that Pierre Rosanvallon also observes that Hayek has "'abandoned' the 'democratic idea,' ... [in] 'radically severing the concept of democracy from legislation' and thereby in insulating legislation from popular sovereignty" (Cornelissen, p. 254, citing Rosanvallon, 2011, p. 153).14

\section{8}

\section{Education}

For Foucault, the fear of power does not in his case give rise to an unbridled love of markets. Foucault makes it clear in "The Risks of Security" that he is no supporter of those who denigrate the state:

In fact, the idea of an opposition between civil society and the state was formulated in a given context in response to a precise intention: some 
liberal economists proposed it at the end of the eighteenth century to limit the sphere of action of the state, civil society being conceived of as the locus of an autonomous economic process. This was a quasi-polemical concept, opposed to administrative options of states of that era, so that a certain liberalism could flourish. (200o, p. 372)

Foucault's writings on neoliberalism represent it as a dis-equalizing and antidemocratic force. ${ }^{15}$ What is more important, however, is that while liberalism represented man as free and uncoerced, who obeyed market laws because they were natural laws, as if ruled by an "invisible hand", in Smith's words, neoliberalism is authoritarian in important respects. This is in the sense that the faltering confidence in laissez-faire and naturalism by liberals led those we can dub as neoliberals to advocate the necessity of the state constructing the "framework" and the "conditions" by which the free market could be assured. What we have seen is that for the German ordoliberals, their distrust in laissez-faire has meant that rather than see the market as natural they see it as historical and in need of conditioning by the state. There is the danger, of course, that this function will be progressively "immunized" from genuine democratic contestation or control.

Amongst the public sector institutions which constitute part of the "conditions" for a competitive market economy, are the various educational institutions, from preschool to higher education, including universities. In higher education, for instance, neoliberal governmentality has subverted what I have called elsewhere a "collegial-democratic" model and replaced it with a new model based upon external audits and performance appraisals, premised upon performance incentive targets and increased monitoring and managerialism. ${ }^{16}$ You can see the top-down, authoritarian aspect of neoliberalism in the new forms of governmentality implemented from the 1980 os in universities. It gives a new significance to the notion of "rule by managers" when one understands that the neoliberal theorists advocated the interpellation of a new strata of managers to counter the classical liberal conception of professionalism, based as it was upon an autonomy of spheres, and to counter it as a form of what Buchanan refers to as "rent-seeking" behaviour. In Britain, four years after Margaret Thatcher was elected, for instance, the Griffith Report of 1983 proposed reforms for the health sector, which included the creation of new senior management roles in the NHS, in order to replace the traditional management functions in health as carried out by professional medical staff. This emergence of a stratum of dedicated professional managers quickly became embedded in legislation and transferred laterally from health to higher education and then across the entire public sector. Ideas of "internal markets" were also current in 
relation to health in the 1980s, and received expression in the 1989 white paper "Working for Patients". New models of "student-led" funding and new corporate managerial models of governance and line management were also implemented at this time, feeding off theoretical ideas developed in supply-side economics, public choice theory, agency theory, and transaction-cost economics. Ideas of line management, based upon "principal-agent" hierarchies of command and compliance replaced "collegial-democratic" patterns of governance based upon classical liberal models of professionalism premised upon autonomy and self-governance, exercised through senates. Suggestions that universities should increase the appointments of lay and business personnel on councils and boards of governors, as advocated in the US by McCormick and Meiners (1988), was intended to reduce academic internal influence and increase the responsiveness of universities to the outside business community. Further governance ideas and techniques saw the downgrading of the influence of senates, as well as the rise of closed "executive boards" to augment the implementation of line-management systems. In Britain, the major responsibility for all of these developments emanates directly from the state through the funding councils. The major levers are all imposed by the state, which itself responds to global interests. The revolution in the way universities were run was worldwide. Collegial models of self-governance premised upon autonomous institutional spheres are replaced by "top-down" managerial models, directed from the centre - the state and global capital.

This also undermines universities semi-autonomous power within civil society, which is itself historically important in terms of understanding liberalism as a natural autonomous system of the different spheres of society and of the free expression of rational individuals. Universities, as once upon a time, a fifth estate, a critical bulwark for the safeguarding of democracy, are now, in this new age of neoliberalism, compromised in relation to the powers of business, superbly administered by the state. The neoliberals' analysis seems particularly apt as a form of market rationality. The abolition of tenure and the enforcement of new norms with regards to research, research funding, and teaching means that most academics are too intent on watching their backs to speak of opposition or serious critique. The assessment of "impact" in Britain escalates this process and seeks now to control and monitor the "content" of what universities produce, to render knowledge production as "useful" for society. In this sense, it constitutes a very worrying "sign", especially given the epistemic difficulties with the way impact is capable of being assessed. The implications for democracy here are in a number of senses: in relation to the end of self-governance through collegial models of academic participation, as well as externally through the erosion of the independent critical authority of 
universities, relatively free of dependence on finance, in relation to business and the state.

In higher education, state conditioning or engineering has substantially undercut the university as a traditional liberal institution. For the difference between liberal and neoliberal is important here. The liberal university was premised upon the freedom of the subject and the dispersal of power across different domains. The parallel at the institutional level was what I have called elsewhere the "collegial-democratic" model administered and managed by academics themselves institutionally provided for by the democratic forum of the senate. ${ }^{17}$ The neoliberal university is top-down, run from the centre. While neoliberals typically heralded their policies with catchcries of freedom and liberty, neoliberalism is in fact a highly centrist, authoritarian, form of liberalism. Distrusting laissez-faire naturalism, they came to share the same perspective on the economy as writers like Karl Mannheim ${ }^{18}$ and Karl Polanyi, ${ }^{19}$ who saw the market order as a historical rather than a natural construct. Whereas Mannheim and Polanyi argued that the government should control and condition the market in order to redistribute wealth in the interests of greater equality and protect freedom, the neoliberals argued that it should work in the interests of capital by creating the conditions for the market to operate as efficiently as possible. The state conditions the market in order that subjects conform.

Perhaps we could conclude this article by asking a number of questions designed to highlight the possible problems with neoliberal governance: Why did the neoliberals feel uneasy with naturalistic explanations of the market and start seeing it as a historical phenomenon that must be conditioned? Is there a problem with naturalistic explanations? Does intervention by the state to establish and maintain the conditions for the market run the risk of frustrating the democratic aspirations and rights of citizens? Could such action by the state be seen to contradict the core principles upon which classical liberalism was founded upon? In whose interests ought the government to act in legislating laws for society? In creating the conditions for competitive market behaviour, is the state reflecting the interests of the whole society or of particular groups in the society? Is it appropriate to subject higher education institutions, such as universities, to market norms of competition as a general strategy of administration and governance? In what ways is education not like other consumer commodities? What are the costs and benefits of such policies in relation to education? The neoliberals said that academics, teachers and educators were not subject to reliable standards of accountability, but could accountability be organized that didn't involve the competitive restructuring of the entire system of education? Do competitive norms conflict with those norms that are deemed to be important in education? What is the difference 
between treating education as a market commodity, as opposed to treating it as a public good? Do supply-side funding policies, such as student fees, exercise conservative pressures on curriculum planners? If so, in what ways? What other effects might they have? Given the relatively modest salaries that are paid to academics and educators, to what extent are academic change-management strategies, such as restructuring, which were initially introduced for those in management on very high incomes, acceptable to use in education institutions? To what extent are managers any less biased or subject to "provider capture" than academics? Have managers or educators and academics become more or less professionalized over the last thirty years? Is there a conflict of interest between professional managers on the one hand and educators on the other?

\section{Acknowledgement}

This chapter originally appeared as Olssen, M. (2018), Neoliberalism and laissez-faire: The retreat from naturalism, Šolsko Polje, 29(1-2), 33-56. Reprinted here, with minor edits, with permission from the publisher.

\section{Notes}

1 In the preparation of the paper, some paragraphs draw from my previous writings on neoliberalism, specifically Olssen (2010, 2016, 2018) and Olssen, Codd, and O'Neill (2004). The publishers of those articles and books are thanked for any replication in this paper.

2 Hayek blames this on the fact that the prevailing conception of democracy is, as Cornelissen puts it, "rooted in the collectivist tradition" and, that as a result, "the particular set of institutions which today prevails in all Western democracies" is inherently inclined towards unlimited government" (2017a, p. 246). Cornelissen cites Hayek, Law, Legislation and Liberty (2013, p. 345); New Studies (1978, pp. 92, 107, 155).

3 "Market Economy and Economic Politics" (translation).

4 Hicks, Kaldor, Lerner, Scitovsky, and Shackle all deserted Hayek, and became Keynesians in the 193 os.

5 See, for instance, Gray (1984), Hindess (1990), Tomlinson (1990), and Gamble (1996).

6 It can be claimed as a bold conjecture at the outset that empirical research has not revealed any significant erosion of democracy in a country like Britain during the period after the inception of the welfare state. Leaders like Asquith claimed that the state was in fact necessary to safeguard freedom.

7 There is no evidence that the development of the welfare state, either in Britain from 1945, or New Zealand from 1933, resulted in an erosion of democracy, or human rights under the law, which, if corroborated, would offer an empirical refutation of Hayek's thesis in The Road to Serfdom (1944). 
8 Hayek, F. A. (1945), "The use of knowledge in society", American Economic Review, 35(4), 519530.

9 Hayek makes this point repeatedly in "The Use of Knowledge in Society" (1945:, pp. 525, 526). My point is that a different type of knowledge, concerned with guidelines, or limits, or "steering", may not be so sensitive to issues of time and place, but may have a longer term frame of reference. An additional point might be that advances in communications technology may make the transmission of what knowledge is relevant to the centre, easier and faster to transmit.

10 Hayek's argument against early communist regimes which sought to replace markets with state planning are indeed valid, but these were based on the idea that markets were not important, and sought amongst other things, to override the price mechanism as a routine matter of policy. I am accepting Hayek's argument that markets convey an important form of knowledge through the price mechanism which determines that the context of operations should be semi-autonomous from the state. This also applies, I would argue, to the family, the educational system, the health system, and personal life, although clearly, there is no such thing as the price mechanism as an indicator of quality. But I am suggesting that the knowledge generated by markets, or in other local contexts, is not the only form of knowledge necessary to a healthy social structure, and that planning can (and must) compliment markets in this quest.

11 Hayek of course sees legislation as emerging in the spontaneous order of society and formed solely out of natural rights. His faltering commitment to laissez-faire and naturalism would make this assumption problematic even on his own terms. But that negative and positive liberty, or state action on such a ground, could be used to justify law vis-à-vis planning is disingenuous. The law even it is claimed only to codify natural rights needs interpreting and being acted upon, and these functions imply a positive dimension to all state action, whether law or planning.

12 He quotes Smith (The Wealth of Nations, Bk. I, 116): "In order, however, that this equality [of wages] may take place in the whole of their advantages or disadvantages, three things are required even when there is perfect freedom. First, the employment must be well known and long established in the neighbourhood"; and David Ricardo (Letters to Malthus, October 22nd, 1811, p. 18): "It would be no answer to me to say that men were ignorant of the best and cheapest mode of conducting their business and paying their debts, because that is a question of fact, not of science, and might be argued against almost every proposition in Political Economy".

13 Unfair, of course, in that Plato was not a democrat, and opposed democracy. Yet, many of the details of Hayek's constitution seem to be excessively protective of the legislators with respect to immunizing them from economic hardship once they have served their time. He specifies, for instance, elaborate conditions and "safeguards" such as that members of the legislature should be elected for reasonably long periods, of 15 years so that they would not be subject to insecurity. Only people "who have proved themselves in the ordinary business of life" should be eligible for election; they should only be removable for "gross misconduct"; after serving their term "they should not be re-eligible nor forced to return to earning a living in the market but be assured of continual public employment". See Law, Legislation and Liberty, Vol. 3, pp. 95-96, 448-45o.

14 Cornelissen argues that the separation of legislation from democracy became increasingly pronounced in Hayek's thought over time, reaching its ultimate status as part of the spontaneous order of society in Volume 3 of Law, Legislation and Liberty. There is, it seems, more scope for further study of Hayek's conception of democracy.

15 But see Zamora and Behrent (2016) who maintain a contrary thesis. 
16 See Raaper and Olssen (2016).

17 Ibid.

18 See Mannheim (1940, 1951/1977).

19 See Polanyi (1944/2001).

\section{References}

Buchanan, J. (1975). The limits of liberty: between anarchy and leviathan. University of Chicago Press.

Cornelissen, L. S. (2017). The market and the people: On the incompatibility of neoliberalism and democracy [Unpublished doctoral dissertation]. University of Brighton.

De Long, J. B. (1990). In defense of Henry Simon's standing as a classical liberal. Cato Journal, 9(3), 601-618.

Eucken, W. (1951). The unsuccessful age, or, the pains of economic progress. William Hodge and Co.

Eucken, W. (1989). What kind of economic and social system? In A. Peacock \& H. Willgerodt (Eds.), Germany's social market economy: Origins and evolution (pp. 27-45). Palgrave Macmillan.

Eucken, W. (1992). Foundations of economics: History and theory in the analysis of economic reality (T. W. Hutchinson, Trans.). Springer Verlag. (Original work published 1940)

Foucault, M. (2000). The risks of security. In J. D. Faubion (Ed.), Essential works of Foucault, 1954-1984, vol. 3: Power (R. Hurley et al., Trans.; pp. 365-381). Penguin.

Foucault, M. (2008). The birth of biopolitics: Lectures at the Collège de France, 1978-79 (G. Burchell, Trans.; M. Senellart, Ed.). Palgrave Macmillan.

Gamble, A. (1996). Hayek: The iron cage of liberty. Avalon.

Gray, J. (1984). Hayek on liberty. Blackwell.

Hayek, F. A. (1944). The road to serfdom. Routledge \& Kegan Paul.

Hayek, F. A. (1945). The use of knowledge in society. American Economic Review, 35(4), 519-530.

Hayek, F. A. (1949a). Economics and knowledge. In F. A. Hayek, Individualism and economic order (pp. 33-56). Routledge \& Kegan Paul.

Hayek, F. A. (1949b). The use of knowledge in society. In F. A. Hayek(Ed.), Individualism and economic order (pp. 77-91). Routledge \& Kegan Paul.

Hayek, F. A. (1949c). The meaning of competition. In F. A. Hayek (Ed.), Individualism and economic order (pp. 92-106). Routledge \& Kegan Paul.

Hayek, F. A. (1949d). Socialist calculation I: The nature and history of the problem. In F. A. Hayek (Ed.), Individualism and economic order (pp. 119-147). Routledge \& Kegan Paul. 
Hayek, F. A. (1949e). Socialist calculation II: The state of the debate. In F. A. Hayek (Ed.), Individualism and economic order (pp. 148-180). Routledge \& Kegan Paul.

Hayek, F. A. (1949f). Socialist calculation III: The "competitive" solution. In F. A. Hayek (Ed.), Individualism and economic order (pp. 181-219). Routledge \& Kegan Paul.

Hayek, F. A. (1954). Marktwirtschaft und Wirtschaftspolitik. ORDO: Jahrbuch für die Ordnung von Wirtschaft und Gesellschaft, 6(4), 3-17.

Hayek, F. A. (1960). The constitution of liberty. Routledge \& Kegan Paul.

Hayek, F. A. (1978). New studies in philosophy, politics, economics and the history of ideas. Routledge.

Hayek, F. A. (2013). Law, legislation and liberty: A new statement of liberal principles of justice and political economy (3 Vols.). Routledge Classics.

Hindess, B. (1990). Liberty and equality. In B. Hindess (Ed.), Reactions to the Right (pp. 7-31). Routledge.

Keynes, J. M. (1980). Keynes letter to Hayek, 28th June 1944. In D. Moggridge (Ed.), Collected writings of John Maynard Keynes, vol. 27: Activities 1940-1946 (pp. 385-388). Macmillan/Cambridge University Press.

Kitch, E. W. (1983). The fire of truth: A remembrance of law and economics at Chicago, 1932-1970. The Journal of Law and Economics, 26(1), 163-234.

Mannheim, K. (1940). Man and society in an age of reconstruction (E. Shils, Trans.). Kegan Paul, Trench, Trubner \& Co.

Mannheim, K. (1977). Freedom, power and democratic planning. Routledge. (Original work published 1951)

McCormack, R. E., \& Meiners, R. E. (1988). University governance: A property rights perspective. The Journal of Law and Economics, 31(2), 423-442.

Olssen, M. (2010). Liberalism, neoliberalism, social democracy: Thin communitarian perspectives on political philosophy and education. Routledge.

Olssen, M. (2016). Neoliberal competition in higher education today: Research, accountability and impact. British Journal of Sociology of Education, 37(1), 129-148. https://doi.org/10.1080/01425692.2015.1100530

Olssen, M. (2018). Neoliberalism \& democracy: A Foucauldian perspective on public choice theory, ordo liberalism and the concept of the public good. In D. Cahill, M. Konings, M. Cooper, \& D. Primrose (Eds.), Sage handbook on neoliberalism (pp. 384396). Sage.

Olssen, M., Codd, J., \& O'Neill, A.-M. (2004). Education policy: Globalization, citizenship \& democracy. Sage.

Polanyi, K. (2001). The great transformation: The political and economic origins of our time (2nd ed.). Beacon Press. (Original work published 1944)

Raaper, R., \& Olssen, M. (2016). Mark Olssen on the neoliberalisation of higher education and academic lives: An interview. Policy Futures in Education, 14(2), 147-163. https://doi.org/10.1177/1478210315610992 
Röpke, W. (1971). A Humane Economy: The Social Framework of the Free Market. Liberty Fund, Inc. (Original work published 1958)

Rosanvallon, P. (2011). Democratic legitimacy: Impartiality, reflexivity, proximity (A. Goldhammer, Trans.). Princeton University Press.

Simons, H. C. (1934). A positive program for laissez-faire: Some proposals for a liberal economic policy. University of Chicago Press.

Simons, H. C. (1948). Economic policy for a free society. University of Chicago Press.

Tomlinson, J. (1990). Market socialism: A basis for socialist renewal? In B. Hindess (Ed.), Reactions to the Right (pp. 32-49). Routledge.

Zamora, D., \& Behrent, M. C. (Eds.). (2016). Foucault and neoliberalism. Polity. 